\title{
SNOW AND GLACIER CONTRIBUTION FROM ITALIAN ALPS FOR SEASONAL RIVER DISCHARGE IN TAGLIAMENTO RIVER
}

\author{
Luminda GUNAWARDHANA $^{1}$ and So KAZAMA ${ }^{2}$ \\ ${ }^{1}$ Member of JSCE, Dr. of Eng., Dept. of Civil Engineering, Tohoku University (Aoba 20, Sendai, 980-8579, Japan) \\ ${ }^{2}$ Member of JSCE, Dr. of Eng., Professor, Dept. of Civil Engineering, Tohoku University (Aoba 20, Sendai, 980- \\ 8579, Japan)
}

\begin{abstract}
This study estimated the contribution of seasonal glacier and snow cover variation on runoff generation in the Tagliamento River catchment in Italy. The normalized difference snow index (NDSI) and band combination method were employed to estimate the glacier and snow melting over different seasons in two catchments and link with the tank model to simulate the river discharge. Approximately $51 \%$ of the catchment area is covered with glacier and snow during the winter, which dramatically reduces to about $5 \%$ during summer. Markedly, $50-75 \%$ of the river discharge from April to June is generated by the glacier and snow melting. With reference to the climate change, it is noted that the snowpack in this region is often close to its melting point (e.g., $-0.9^{\circ} \mathrm{C}$ in February), which may respond rapidly even to minor changes in temperature $\left(62 \mathrm{~km}^{2} /{ }^{\circ} \mathrm{C}\right)$ resulting possible early season runoff. The dependency of the model parameters on different climatic and geographical settings was also discussed.
\end{abstract}

Key Words : snow melt, Seasonal river discharge, Tank model, Italian Alps

\section{INTRODUCTION}

The impacts of climate change on water systems are mainly due to the observed and projected increases in temperature and precipitation variability $^{1)}$. The mountain glaciers and snow cover depletion is perhaps the most obvious evidence of the changing climate. The Alps, commonly known as the Water Tower of Europe, is facing serious threat to alter the Alpine water cycle drastically.

In mountainous areas, water is collected and stored as snow and ice in glaciers during winter. It is then slowly released as the ice and snow melt throughout spring and summer, feeding rivers such as the Tagliamento, Italy. This makes water available in the downstream when rainfall is dropping, and when demand is high. Changes in precipitation, snowcover patterns and glacier storage are expected to alter the way water is transported. Higher temperatures generate increased glacier $\mathrm{melt}^{2}$. Consequently, the seasonal shift in stream flow, and the reduction in low flows during spring and summer will have substantial impact not only on the ecological balance of the river systems but also the social and economical sectors such as community water supply, irrigation and hydro power generation.

Alpine climates have undergone significant change over the past century. From 1850 to 1980 , glaciers in the European Alps lost approximately one third of their area and one half of their mass. Especially annual average temperatures have risen by up to $2^{\circ} \mathrm{C}$ in many parts of Alps between 1901 and 2000, which is well above the global-average $20^{\text {th }}$ century warming ${ }^{1)}$. Durand et al. ${ }^{3)}$ based on 44 years climatic records (1958-2002), report that temperatures in Alps are rising in spring, but falling in autumn. Particularly late winter and early summer temperature during recent years remained constantly high. These changes pose serious concern on the greater variability and seasonal shift in river flow during main seasons throughout the year. In recent years, there have been increasing attempts to evaluate the climate change impacts on mountain glaciers and snow cover in Alps and associate stream flow variations in rivers such as the Danube, Rhine and Rhone. However, the attention on Tagliamento River in Italy, which is considered as the last morphologically intact river in Alps, is 
comparatively low. In particular, there has been no research to estimate the glacier and snow contribution in different seasons for stream flow generation. Therefore, the main objective of this paper is to estimates the average contribution of snow and glacier melt runoff in variation of water flow in Tagliamento River. These estimations will be practically important with emerging vulnerability of glacier and snow resources under changing climate conditions for water resources development of the region.

\section{METHODOLOGY}

\section{(1) Study area}

Tagliamento River in northeastern Italy flows from the Italian Alps to the Adriatic Sea. The study area of our interest includes two catchments covering $1085 \mathrm{~km}^{2}$ for Tolmezzo and $1935 \mathrm{~km}^{2}$ for Venzone with elevations ranging from $370 \mathrm{~m}$ at the catchment outlet to $2600 \mathrm{~m}$ at northeastern Alpine areas (Fig. 1). The mean annual air temperature is $7.8^{\circ} \mathrm{C}$, with mean daily temperature remaining below $2^{\circ} \mathrm{C}$ for an average of 93 days in each year. The rate of temperature decrease with elevation is about $4.7^{\circ} \mathrm{C}$ per $1000 \mathrm{~m}$. Mean annual precipitation is approximately $2600 \mathrm{~mm}$. The seasonal snow cover begins to accumulate in late November or early December (average temperature $<0^{\circ} \mathrm{C}$ ) and snowmelt typically commences at the end of March or the start of April (average temperature $<5^{\circ} \mathrm{C}$ ). Low flows generally prevail over the winter, while most incident precipitation accumulates as snow. This is followed by a sustained period of high flows during the spring (in late April to early June) resulting from melting of the winter snowpack. Flow generally declines after snow disappears from the catchment in early summer. Meteorological records at 11 stations and river discharge collected over 1-hr interval (one year for Tolmezzo and two years for Venzone) were used for the analysis.

\section{(2) Tank model for runoff simulations}

The tank model proposed by Sugawara ${ }^{4)}$ is a simple non-linear rainfall-runoff model composed of one or several tanks (Fig. 2). The coefficients represented for different hydrological processes (surface and subsurface runoff and infiltration) are generally obtained by matching observed and simulated data. Magnitude differences of these coefficients in different catchments reflect the geographical features of the watersheds ${ }^{5}$. The glacier and snow melt is taken to the simulation as single water body and summed up with rainfall to put in to the first tank at the top. Evapotranspiration is directly subtracted from the top tank. Among the

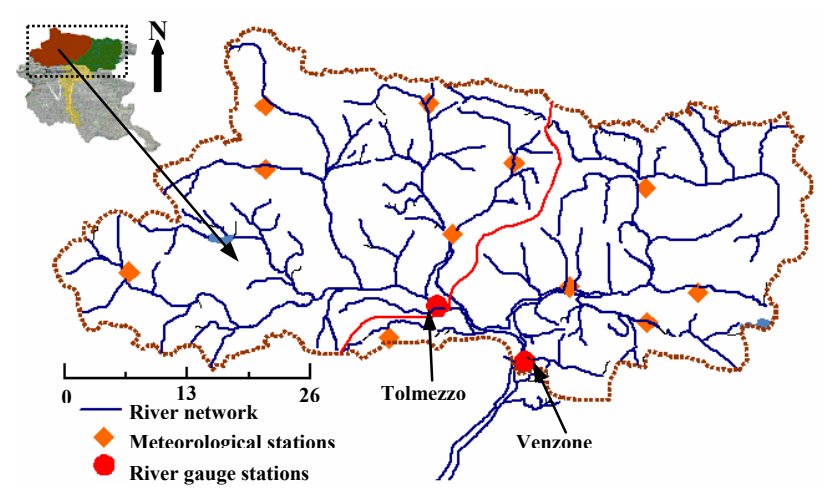

Fig.1 Catchment areas in the Tagliamento River basin.

four tanks in the model, first tank at the top account for rapid runoff near the ground surface and second tank models the shallow subsurface runoff process. Other two tanks at the bottom delayed surplus water from the top two tanks. This phenomenon represents hydrological role of the deep aquifers that accumulate the infiltrating water from the ground surface and released in to the downstream with certain time delays. Representative mathematical model for the water exchange between tanks and daily runoff generation can be expressed as follows.

$$
\begin{gathered}
R_{(x, n)}= \begin{cases}A_{(x)} \times\left[H_{(x, n)}-Z_{(x)}\right] & H_{(x, n)}>Z_{(x)} \\
0 & H_{(x, n)} \leq Z_{(x)}\end{cases} \\
I_{(x, n)}=B_{(x)} \times H_{(x, n)} \\
H_{(x, n+1)}=\left\{\begin{array}{c}
H_{(x, n)}-\left[R_{(x, n)} \times \Delta t\right]-\left[I_{(x, n)} \times \Delta t\right]+\left[T_{(n+1)} \times \Delta t\right] x=1 \\
H_{(x, n)}-\left[R_{(x, n)} \times \Delta t\right]-\left[I_{(x, n)} \times \Delta t\right]+\left[I_{(x-1, n)} \times \Delta t\right] x \neq 1 \\
T_{(n)}=P_{(n)}+S M_{(n)}-E v t_{(n)} \\
Q_{(n)}=\sum_{x=1}^{4} R_{(x, n)}
\end{array}\right.
\end{gathered}
$$

where

$x$ : number of tanks counted from top

$n: \quad$ number of days from the beginning (1/d)

$\Delta t: \quad$ length of time step

$A_{(x)}$ : runoff coefficient of $x^{\text {th }} \operatorname{tank}(1 / \mathrm{d})$

$B_{(x)}$ : infiltration coefficient of $x^{\text {th }} \operatorname{tank}(1 / \mathrm{d})$

$H_{(x, n)}$ : water depth in $x^{\text {th }}$ tank at $n^{\text {th }}$ day $(\mathrm{mm})$

$Z_{(x)}$ : height of runoff hole of $x^{\text {th }} \operatorname{tank}(\mathrm{mm})$

$R_{(x, n)}: \quad$ runoff from $x^{\text {th }}$ tank at $n^{\text {th }}$ day $(\mathrm{mm} / \mathrm{d})$

$I_{(x, n)}$ : infiltration in $x^{\text {th }}$ tank at $n^{\text {th }}$ day $(\mathrm{mm} / \mathrm{d})$

$T_{(n)}$ : total input to first tank at $n^{\text {th }}$ day $(\mathrm{mm} / \mathrm{d})$

$S M_{(n)}:$ snow melt at $n^{\text {th }}$ day $(\mathrm{mm} / \mathrm{d})$

$E v t_{(n)}: \quad$ evapotranspiration at $n^{\text {th }}$ day $(\mathrm{mm} / \mathrm{d})$

$Q_{(n)}: \quad$ total runoff at $n^{\text {th }}$ day $(\mathrm{mm} / \mathrm{d})$

$P_{(n)}$ : $\quad$ precipitation at $n^{\text {th }}$ day $(\mathrm{mm} / \mathrm{d})$

Two tank models for Tolmezzo and Venzone catchments were developed. When snow melt is assumed to be a function of mean air temperature of the day, degree-day method can be employed to 


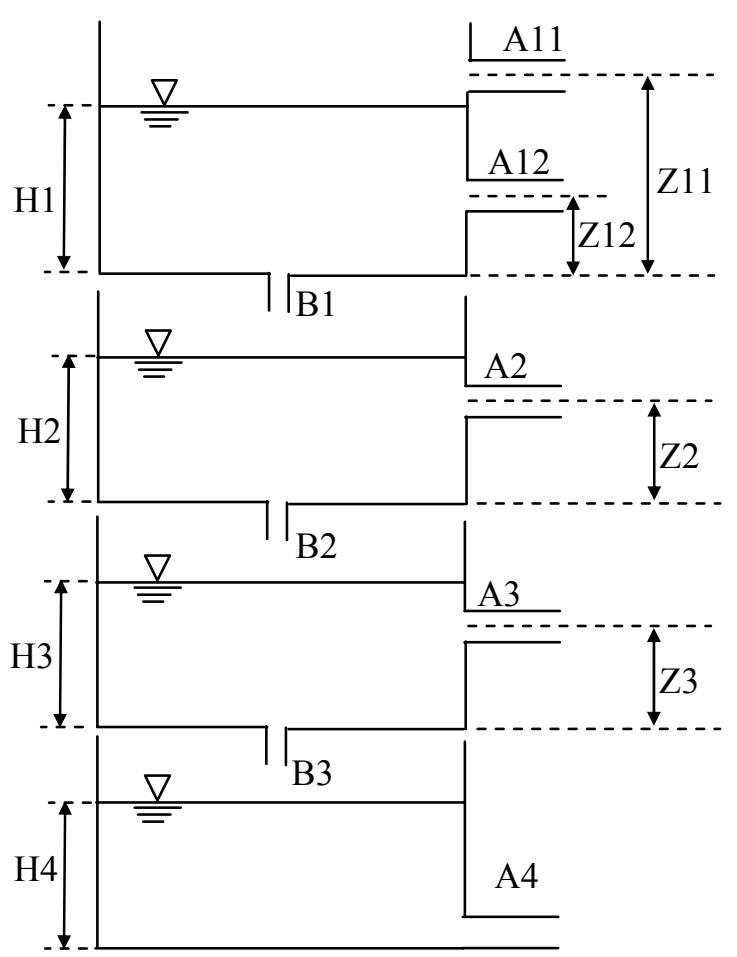

Fig.2 Tank model structure for runoff simulations.

estimate the snow melt (Eq.6).

$$
S M=K \times T
$$

where $T$ is the mean daily temperature $\left({ }^{\circ} \mathrm{C}\right)$ and $K$ is the degree day parameter $\left(\mathrm{mm} /{ }^{\circ} \mathrm{C} / \mathrm{d}\right)$. Only one parameter that needs to be estimated makes this method easy to apply in climate change studies. This is because, due to the higher level of uncertainties incorporate in general circulation model output (e.g., temperature, precipitation, humidity etc.), use of many climatic parameters for impact predictions eventually increase the uncertainty of the final output ${ }^{6}$. The Food and Agriculture Organization (FAO-56) modified Hargreaves equation, one of the widely used temperature based method, was used for estimating reference evapotranspiration $\left(\mathrm{ET}_{0}\right)$.

$$
E T_{0}=\frac{0.0023}{\lambda}\left(\frac{T_{\max }+T_{\min }}{2}+17.8\right) \times \sqrt{T_{\max }-T_{\min }} \times R_{a} \text { (7) }
$$

where $T_{\max }\left({ }^{\circ} \mathrm{C}\right)$ is the maximum daily air temperature, $T_{\min }\left({ }^{\circ} \mathrm{C}\right)$ is the minimum daily air temperature, $R_{a}\left(\mathrm{MJ} / \mathrm{m}^{2} / \mathrm{d}\right)$ is the extra-terrestrial solar radiation and $\lambda$ is the latent heat of vaporization $\left(2.45 \mathrm{MJ} / \mathrm{m}^{2} / \mathrm{d}\right)$. Evapotranspiration losses from the basin are taken into account only from the snow free area as the evaporation losses from the rain falling on the snow covered area can be taken to be negligible. The glacier and snow covered area in the basin was determined using satellite data. The Landsat TM and ETM+ scenes during 2001-2003 time period were selected at $30 \mathrm{~m}$ grid resolution such a way that the maximum cloud cover is always less than $15 \%$. In order to represent temporal change of the snow cover, several Landsat scenes covering every season were collected. On Landsat scenes, the glacier and snow spectral values accounted as 255, 145-255, 191-255, 116-217, 2031 and 3-18 in each bands 1-5 and 7, respectively ${ }^{7}$. At the initial stage, these spectral ranges were used as a reference for snow and glacier classification. Next, bands combination method is used by assigning three primary colors (RGB) to three bands. Three band combinations; 3,2,1 and 4,3,2 and 5,4,3 were used and compared with each other to identify the areas with similar land classes. In order to distinguish glacier and snow from similarly bright soil, rocks and clouds, normalized difference snow index (NDSI) was also applied (Eq. 8).

$$
N D S I=\frac{(T M 2-T M 5)}{T M 2+T M 5}
$$

\section{RESULTS AND DISCUSSION}

To understand the seasonal pattern of snow and glacier cover variation, Landsat scenes were analyzed using band combination method and arithmetic operations of NDSI index. Fig. 3 depicts the discriminated glacier and snow area for Tolmezzo catchment during intense snowfall (Feb 15) and snow disappeared (Aug 26) time periods. Snow and glacier areas mapped by band combination method is shown in light blue for 5,4,3 band combination (Fig. 3a) and in white color for 4,3,2 combination (Fig. 3b). Fig. 4 shows the transient change of snow cover in different seasons of the year. Many studies used 0.4 threshold for NDSI index for identifying glacier and snow covered area. In our study, by comparing glacier and snow cover variation during winter and summer from several scenes, $0.35 \mathrm{NDSI}$ value was identified as the best threshold to distinguish the glacier and snow cover areas. The output from the band combination method and NDSI index reveal that snow melt starts first in the low elevation areas of the catchment, where usually, the snow cover is thin and air temperature is high. Subsequently, as temperature increases from winter to summer, the melt continues to the upper part of the catchment. According to Fig. 4, air temperatures over the melt period represent the depletion of snow cover. The seasonal snow cover tends to disappear at a faster rate during warmer climatic conditions (MarchJune), while it will follow slow depletion under a colder temperature regime (December-February). It is estimated that on an average about $51 \%$ area of the basin is covered with snow and glacier during December to February, which reduces to about 5\% during July to September. Substantial melting rate of winter snow pack during this period must have contributed to a sustained period of high river flows 




Fig. 3 Glacier and snow cover change during two time periods.

during the spring and early summer. Fig. 5 depicts the observed and simulated river discharges at Tolmezzo and Venzone gauge stations. Simulated water discharges agreed with the corresponding observations, with coefficient of determination $\left(\mathrm{R}^{2}\right)$ equals to 0.84 and 0.82 for Tolmezzo and Venzone catchment areas, respectively. According to Fig. 5, substantially higher river flow can be seen during spring season, in particular from early May to early June, 2009. Total river discharge in this period account for $12 \%$ and $10 \%$ of annual river discharges at Tolmezzo and Venzone catchment areas, respectively. However, it is worth noticing that the precipitation in this period is comparatively small, giving only less than $5 \%$ of the annual precipitation. According to the simulated results, $75 \%$ and $50 \%$ of the river discharges from May to June are generated by the glacier and snow melting at Tolmezzo and Venzone catchment areas, respectively. In total, the average snow and glacier runoff contribution in the annual flow of Tagliamento River is estimated to be about $48 \%$ and $33 \%$ at Tolmezzo and Venzone gauge stations, respectively.

(1) Model parameter dependency on different geographical and climatic settings

The coefficients of the tank model represent different hydrological processes of the catchment ${ }^{5}$. As example, larger A1 coefficient produces higher

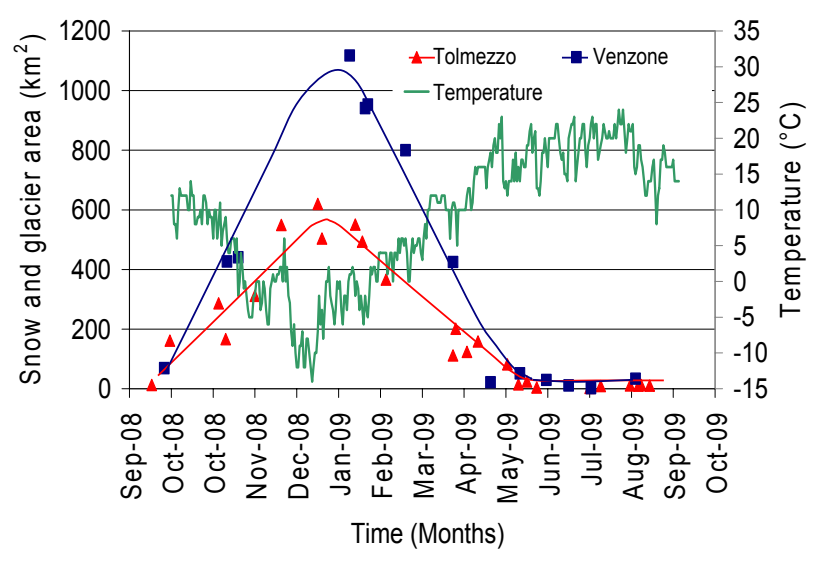

Fig. 4 Seasonal change of snow cover area.

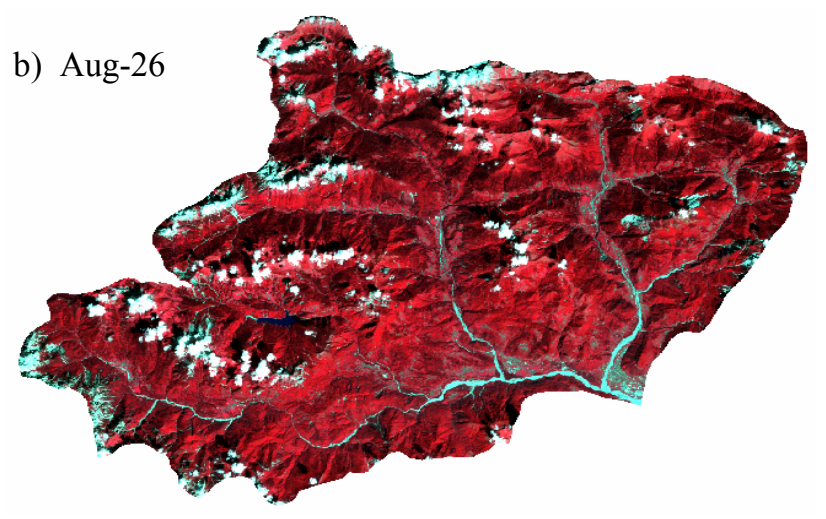

rapid surface runoff near the ground surface, while larger B1 coefficient stands for higher infiltration capacity. Table 1 shows the derived model parameters for two catchments.

\section{a) Parameter dependency on vegetation cover}

According to Table 1, B coefficients between two catchments depict significant differences, while other parameters have approximately similar magnitudes. These variations indicate that the Venzone catchment has higher infiltration capacity than the Tolmezzo, which may be attributed to the different site conditions of the two catchments. Fig. 6 depicts the change of NDVI value in different intervals between two catchments. Higher level of biomass in the catchment is generally represented
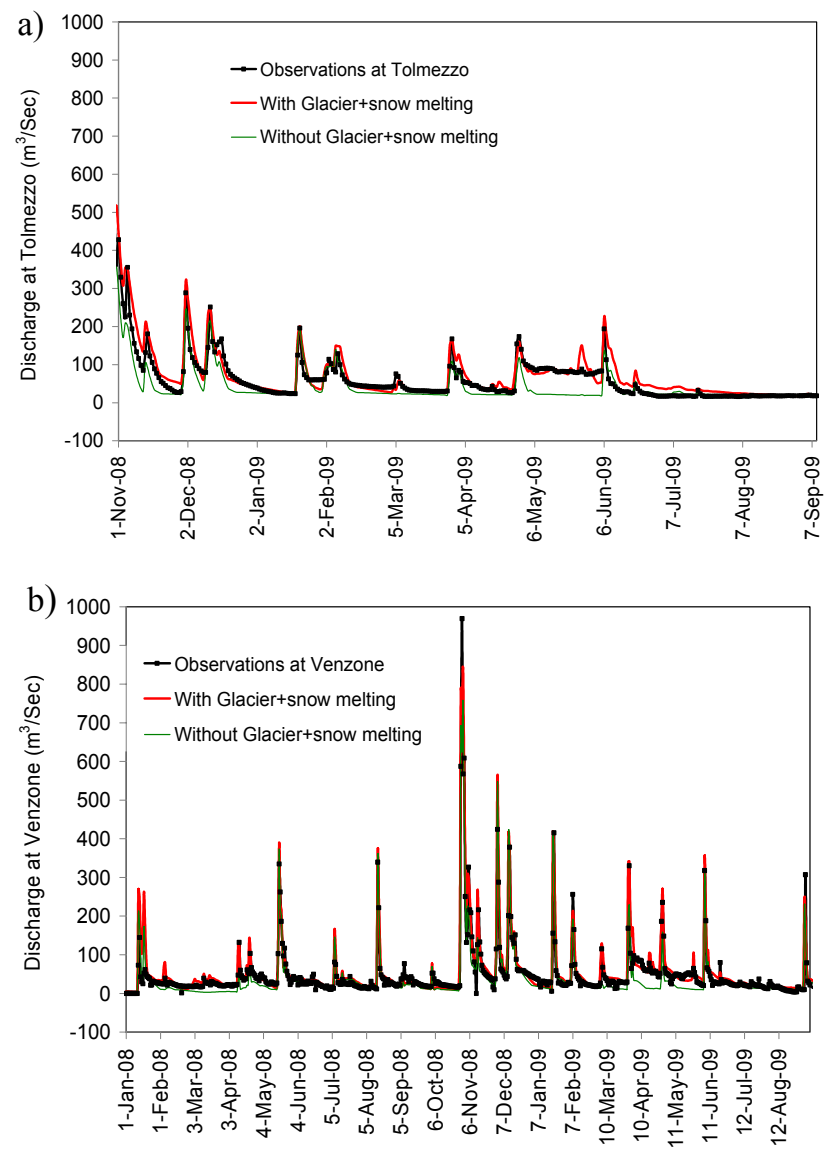

Fig. 5 Simulated discharges a) at Tolmezzo and b) at Venzone. 
Table 1 Tank model coefficients in different catchments

\begin{tabular}{|l|c|c|c|c|c|c|c|c|}
\hline & $\mathrm{A} 11$ & $\mathrm{~A} 12$ & $\mathrm{~B} 1$ & $\mathrm{~A} 2$ & $\mathrm{~B} 2$ & $\mathrm{~A} 3$ & $\mathrm{~B} 3$ & $\mathrm{~A} 4$ \\
\hline Venzone & 0.17 & 0.05 & 0.20 & 0.03 & 0.10 & 0.007 & 0.050 & 0.0001 \\
\hline Tolmezzo & 0.13 & 0.04 & 0.08 & 0.03 & 0.03 & 0.007 & 0.008 & 0.0001 \\
\hline S. Japan* & 0.4 & 0.2 & 0.15 & 0.1 & 0.05 & 0.020 & 0.030 & 0.0030 \\
\hline & $\mathrm{Z} 11$ & $\mathrm{Z} 12$ & $\mathrm{Z} 2$ & $\mathrm{Z} 3$ & $\mathrm{H} 4$ & $\mathrm{H} 3$ & $\mathrm{H} 2$ & $\mathrm{H} 1$ \\
\hline Venzone & 50 & 40 & 30 & 10 & 200 & 40 & 10 & 1 \\
\hline Tolmezzo & 45 & 35 & 30 & 10 & 200 & 40 & 10 & 1 \\
\hline S. Japan* & 40 & 15 & 20 & 10 & 200 & 40 & 2 & 1 \\
\hline
\end{tabular}

*based on 12 catchments in southern Japan from Yokoo et al. ${ }^{5)}$

by larger NDVI values. According to Fig. 6, approximately similar percentages of biomass in two catchments indicate that land cover difference may have no significant effect on different hydrological processes of the two catchments. When other site conditions are approximately similar, higher biomass percentage in a catchment result for lower surface runoff production. Therefore, slightly higher percentage of vegetation cover in Tolmezzo catchment between 0.3-0.6 NDVI ranges may stand for slightly low runoff coefficient (A11) in Tolmezzo than in Venzone catchment.

\section{b) Parameter dependency on topography}

Comparatively small change of land covers between two catchments suggests that differences of other site conditions may have produced different infiltration parameters for two catchments. Therefore, the geographical effect for various runoff processes was considered by analyzing the representative gradient $(R G)$ of the two catchments. The elevation difference between the highest elevated point and catchment outlet was first calculated and later divided by the horizontal distance between two points to obtain the RG. For a better accuracy of our estimations, Tolmezzo and Venzone catchments were further subdivided for 7 and 13 small catchments and RG was calculated in each sub-catchment. Representative RG for Tolmezzo and Venzone catchments was estimated by averaging the RGs in corresponding subcatchments. According to these estimations, averaged RG for the Tolmezzo catchment is 0.085

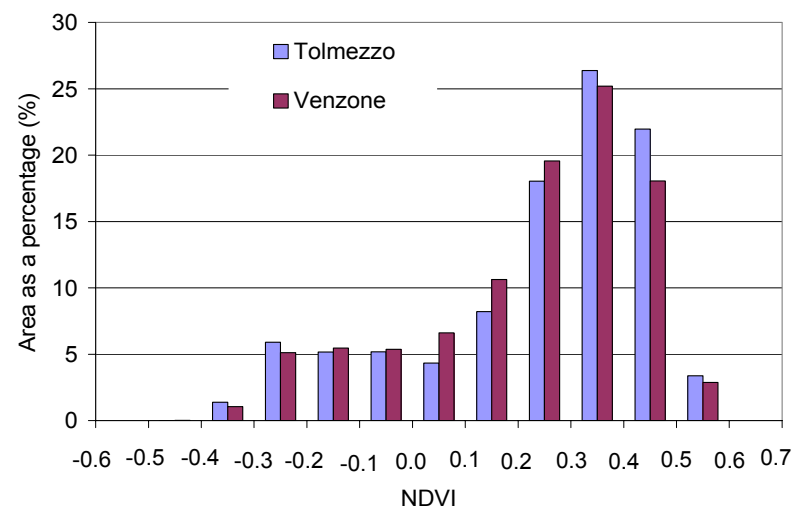

Fig. 6 Change of NDVI on 29-Jul-2002 in two catchments. (variance $\left.\left(\sigma^{2}\right)=0.0021\right)$ and 0.065 for Vanzone catchment $\left(\sigma^{2}=0.0019\right)$. Comparatively higher RG in Tolmezzo catchment (30\% larger than RG in Venzone) confirms the presence of small infiltration capacity of the catchment (i.e., small B coefficients) than the Venzone. Moreover, slightly higher Z11 and Z12 values in Venzone catchment than in Tolmezzo may indicate the ability of low steep catchment to have a larger storage capacity.

\section{c) Parameter variations in different regions}

Table 1 shows the derived Tank model parameters for 12 catchments in southern Japan ${ }^{5)}$. Average RG of these catchments is $0.051\left(\sigma^{2}=0.0002\right)$, which is reasonably smaller than RGs of catchments in Alps. Therefore, despite the effects of different geological and land use settings to generate different model parameters, A11 and A12 coefficients in Japanese catchments can be expected to have smaller magnitude than Alps catchments. In contrast, while other parameters remain in approximately similar magnitudes, surface runoff parameters alone show distinct behavior, where they are considerably larger in Japanese catchments than in Alps. This phenomenon can be explained with the difference of precipitation form in these regions. In Alps catchments, major part of precipitation is occurred as snow, which covered $51 \%$ of the basin area during winter. This water is then slowly released as snow melts throughout spring and summer with certain time delay. However, catchments in southern Japan experience very little effect of nnow $^{5)}$. Therefore, rainfall water rapidly converts to runoff with no time delays as from snow melt. For this reason, Alps catchments generate smaller surface runoff coefficients for the tank models than in Japanese catchments. Similarly, they have slightly larger storage capacities (Z11, Z12 and Z2) than the Japanese catchments.

\section{(2) Sensitivity of glacier and snow areas to climate variations}

Fig. 7 shows the response of snow cover to seasonal temperature variations at Tolmezzo catchment. Venzone catchment also shows similar response, where glacier and snow cover change follows the trend of temperature variation. Once air temperature is passing $0^{\circ} \mathrm{C}$ threshold, snow cover area is starting to deplete in a rate of $4.2 \mathrm{~km}^{2} /$ day, which is almost constant until the end of May. When this trend is compared with the seasonal warming trend in the area, approximately $62 \mathrm{~km}^{2} /{ }^{\circ} \mathrm{C}$ melting rate could be estimated (gradient of Fig.7). Beniston et al. ${ }^{8)}$ show that winter temperatures in the European Alps under A2 scenario will increase by $4^{\circ} \mathrm{C}$. In such situation, Alps mountain region where the snowpack is often close to its melting point (e.g., 


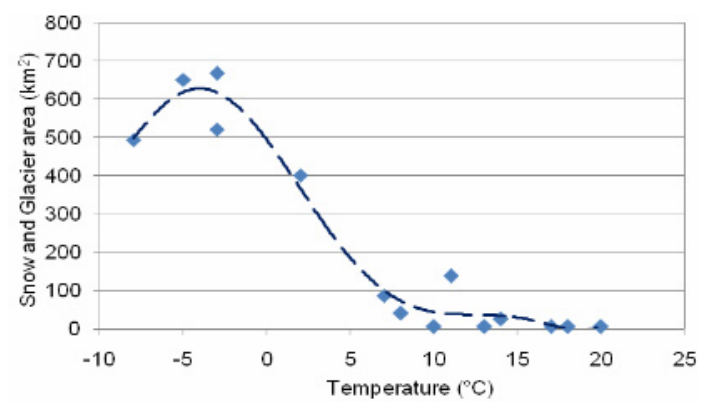

Fig. 7 Response of snow area to seasonal temperature change.

average temperature in February $=-0.9^{\circ} \mathrm{C}$ ) may have critical impact such that responding rapidly to minor changes in temperature. Consequently, reduction in snow cover will have a number of implications, in particular for early season runoff, and increasing water temperature. According to the simulated water discharge in Fig. 5, precipitation contribution alone is unlikely sustain the water flow during the spring and summer seasons (green line in the figure). Especially, from early May to early June, it is possible that river discharge may dry out or substantially lower without adequate snowmelt. Such impact not only affects the mountains ecology but also lowland regions that depend on mountain water for domestic, agricultural, energy supply.

\section{CONCLUSIONS}

Seasonal snow cover is important in assessing water availability in the Tagliamento River under changing climate conditions. In our study, Landsat scenes were used to evaluate seasonal change of snow cover, which later linked with a hydrological model to estimate the snow melt contribution for river discharge from two catchments. These estimations lead us to following conclusions.

1. Approximately half of the catchment area (51\%) is covered with glacier and snow during the winter, which dramatically reduces to about $5 \%$ during summer. In total, the average snow and glacier runoff contribution in the annual flow of Tagliamento River is estimated to be ranged 33$48 \%$. This contribution is high as $50-75 \%$ from April to June, which confirmed very significant glacier and snow melting contribution for river discharge in the Tagliamento River catchment.

2. The land cover differences between two catchments have minor effect on model parameter variations, but topographic effect in terms of representative gradient proved to be effective in determining runoff and infiltration coefficients.

3. Tank model parameters successfully account the climatic variations in different regions, where better results can be achieved for rivers with higher proportion of glacier and snow feeds by adjusting the model parameters to suit with the snow and glacier melt.

4. The snowpack in this region is often close to its melting point (e.g., $-0.9^{\circ} \mathrm{C}$ in February), which may respond rapidly even to minor changes in temperature $\left(62 \mathrm{~km}^{2} /{ }^{\circ} \mathrm{C}\right)$. In particular, early May to early June was identified as the most critical time period, where the river flow may almost dry out without adequate glacier and snow contribution. Such impact will adversely affect for all dependent not only in the Tagliamento River catchment but also populated downstream areas.

ACKNOWLEDGMENT: This research was supported by the Environment Research and Technology Development Fund (S-8) of the Ministry of the Environment, Japan and Ministry of Education, Science, Sports and Culture, Grant-inAid for Scientific Research (A), 2010-2013 (21254003) and (B), 2010-2013 (22360192).

\section{REFERENCES}

1) Parry, M., Canziani, O., Palutikof, J., Linden, P.V. and Hanson, C.: Climate change 2007: Impacts, Adaptation and Vulnerability. Summary for policymakers. Cambridge University Press: New York; 11, 2007.

2) Schneeberger, C., Blatter, H., Abe-Ouchi, A., and Wild, M.: Modelling changes in the mass balance of glaciers of the northern hemisphere for a transient $2 \times \mathrm{CO}_{2}$ scenario, Journal of Hydrology, Vol.282, pp.145-163, 2003.

3) Durand, Y., Giraud, G., Laternser, M., Etchevers, P., Lesaffre, B. and Merindol, L.: 44 Years of climate reanalyses in the French Alps (1958-2002): methodology, validation and results for the main meteorological parameters and related snow cover conditions. Geophysical Research Abstracts, Vol. 9, pp.1-2, 2007.

4) Sugawara, M., Tank model, Computer models of watershed hydrology, Singh, V. J. ed., Water Resources Publications, Highlands Ranch, CO, USA, 1995.

5) Yokoo, Y., Kazama, S., Sawamoto, M. and Nishimura, H.: Regionalization of lumped water balance model parameters based on multiple regression, Journal of Hydrology, Vol.246, pp.209-222, 2001.

6) Salathe Jr, E. P., Mote, P. W. and Wiley, M. W.: Review of scenario selection and downscaling methods for the assessment of climate change impacts on hydrology in the United States Pacific Northwest, Int. J. Climatology, Vol.27, pp.1611-1621, 2007.

7) Erdenetuya, M., Khishigsuren, P., Davaa, G. and Otgontogs, M.: Glacier change estimation using Landsat TM data, Int. Archives of the Photogrammetry, Remote Sensing and Spatial Information Sceince, Vol.36, pp.240-243, 2006.

8) Beniston, M., Keller, F., Koffi, B. and Goyette, S.: Estimates of snow accumulation and volume in the Swiss Alps under changing climate conditions, Theor. Appl. Climatol., Vol.76, pp.125-140, 2003. 